\title{
CHARACTERIZATION OF ZnO NANOFIBER ON DOUBLE-LAYER DYE-SENSITIZED SOLAR CELLS USING DIRECT DEPOSITION METHOD
}

\section{CHARACTERIZATION OF ZnO NANOFIBER ON DOUBLE-LAYER DYE-SENSITIZED SOLAR CELLS USING DIRECT DEPOSITION METHOD}

\section{KARAKTERISASI ZnO NANOFIBER PADA SEL SURYA TERSENSITISASI PEWARNA DENGAN LAPISAN GANDA MENGGUNAKAN METODE DIRECT DEPOSITION}

\author{
ARIFIN, Zainal ${ }^{1, *}$, HADI, Syamsul ${ }^{1}$, SUYITNO, Suyitno ${ }^{1}$, PRABOWO, Aditya Rio ${ }^{1}$, \\ PRASETYO, Singgih Dwi ${ }^{1}$ \\ 1 Department of Mechanical Engineering, Universitas Sebelas Maret, JI. Ir. Sutami No.36A, Jebres, Surakarta \\ 57126, Indonesia. \\ * Corresponding author \\ e-mail: zainal_arifin@staff.uns.ac.id
}

Received 02 September 2020; received in revised form 19 October 2020; accepted 11 November 2020

\begin{abstract}
Characterization
Solar cells are capable of harvesting energy by converting solar heat into electrical energy through the photovoltaic process. A type of solar cell, namely dye-sensitized solar cells (DSSCs) which based on doublelayer photoanode is attracting researchers and engineers considering its characteristics, e.g., high efficiency, low cost, and available mass-production. The $\mathrm{TiO}_{2}-\mathrm{ZnO}$ double-layer semiconductor can be obtained from a nanofiber $\mathrm{ZnO}$ semiconductor which is deposited with a $\mathrm{TiO}_{2}$ nanoparticle semiconductor. In this study, the direct deposition method was applied using an electrospinning machine. The intention is to directly capture the liquid of electro-jet spun from PVA/Zn(Ac) 2 solution onto fluorine-doped tin oxide (FTO) glass. The glass itself is coated with $\mathrm{a} \mathrm{TiO}_{2}$ nanoparticle semiconductor. The investigation was addressed to obtain the best tip distance to the collector and the best flow rate in the electrospinning process. The subject environment was designated on the manufacturing process of nanofiber $\mathrm{ZnO}$ semiconductors used as double-layer DSSC photoanodes. Variations in flow rates of $3,4,5,6,7$, and $8 \mu \mathrm{L} /$ minute were applied in the observation. Furthermore, collaboration with the tip to collector distances using a variation of $3,4,5,6,7$, and $8 \mathrm{~cm}$ was also considered in this study. Based on these parameters, the effects of the electrospinning process on the morphology of the directly deposited $\mathrm{ZnO}$ nanofiber semiconductor were obtained. The results showed that a flow rate of 4 $\mu \mathrm{L} /$ minute and a tip distance to the collector of $8 \mathrm{~cm}$ produced a small diameter and uniform morphology. This morphology allowed $\mathrm{ZnO}$ nanofibers to have better color absorption and electron excitation. Thus, it was directly proportional to the high efficiency of double-layer DSSCs. The performance value for the $4 \mu \mathrm{L} / \mathrm{min}$ discharge was $2.39 \%$, and the performance value for the $8 \mathrm{~cm}$ needle tip distance to the collector was $1.61 \%$.
\end{abstract}

Keywords: semiconductors, double layer, direct deposition, dye-sensitized solar cells (DSSCs)

\section{ABSTRACT}

Solar cells are capable of harvesting energy by converting solar heat into electrical energy through the photovoltaic process. A type of solar cell, namely dye-sensitized solar cells (DSSCs) which based on doublelayer photoanode is attracting researchers and engineers considering its characteristics, e.g., high efficiency, low cost, and available mass-production. The $\mathrm{TiO}_{2}-\mathrm{ZnO}$ double-layer semiconductor can be obtained from a nanofiber $\mathrm{ZnO}$ semiconductor which is deposited with a $\mathrm{TiO}_{2}$ nanoparticle semiconductor. In this study, the direct deposition method was applied using an electrospinning machine. The intention is to directly capture the liquid of electro-jet spun from PVA/Zn(Ac) 2 solution onto fluorine-doped tin oxide (FTO) glass. The glass itself is coated with $\mathrm{a} \mathrm{TiO}_{2}$ nanoparticle semiconductor. The investigation was addressed to obtain the best tip distance to the collector and the best flow rate in the electrospinning process. The subject environment was designated on the manufacturing process of nanofiber $\mathrm{ZnO}$ semiconductors used as double-layer DSSC photoanodes. Variations in flow rates of $3,4,5,6,7$, and $8 \mu \mathrm{L} /$ minute were applied in the observation. Furthermore, collaboration with the tip to collector distances using a variation of $3,4,5,6,7$, and $8 \mathrm{~cm}$ was also considered in this study. Based on these parameters, the effects of the electrospinning process on the morphology of the directly deposited $\mathrm{ZnO}$ nanofiber semiconductor were obtained. The results showed that a flow rate of 4 
$\mu \mathrm{L} /$ minute and a tip distance to the collector of $8 \mathrm{~cm}$ produced a small diameter and uniform morphology. This morphology allowed $\mathrm{ZnO}$ nanofibers to have better color absorption and electron excitation. Thus, it was directly proportional to the high efficiency of double-layer DSSCs. The performance value for the $4 \mu \mathrm{L} / \mathrm{min}$ discharge was $2.39 \%$, and the performance value for the $8 \mathrm{~cm}$ needle tip distance to the collector was $1.61 \%$.

Keywords: semiconductors, double layer, direct deposition, dye-sensitized solar cells (DSSCs)

\section{ABSTRAK}

Sel surya merupakan alat pemanen energi dengan mengubah panas matahari menjadi energi listrik melalui proses fotovoltaik. Salah satu jenis sel surya, yaitu sel surya tersensitisasi pewarna (dye-sensitized solar cells atau DSSC). Fotoanoda DSSC dengan struktur lapisan ganda menarik para cendekiawan untuk melakukan observasi dan riset, karena memiliki efisiensi tinggi, biaya produksi rendah, dan kemampuan produksi secara massal. Semikonduktor dengan struktur lapisan ganda berupa $\mathrm{TiO}_{2}-\mathrm{ZnO}$ dapat diperoleh dari semikonduktor nanofiber $\mathrm{ZnO}$ yang dideposisikan dengan semikonduktor nanopartikel $\mathrm{TiO}_{2}$. Pendeposisian dapat dilakukan dengan metode direct deposition menggunakan bantuan mesin elektrospinning. Tujuannya adalah untuk secara langsung menangkap cairan elektro-jet yang dipintal dari larutan $\mathrm{PVA} / \mathrm{Zn}(\mathrm{Ac})_{2}$ ke gelas oksida timah yang didoping fluor $(F T O)$ yang terlapisi semikonduktor nanopartikel $\mathrm{TiO}_{2}$. Studi ini ditujukan untuk mendapatkan jarak ujung jarum ke kolektor dan debit aliran terbaik dalam proses elektrospinning secara direct deposition. Eksperimen dilakukan pada proses pembuatan semikonduktor nanofiber $\mathrm{ZnO}$ yang digunakan sebagai fotoanoda DSSC dengan struktur lapisan ganda. Debit aliran dengan nilai 3, 4, 5, 6, 7, dan $8 \mu \mathrm{L} / \mathrm{menit}$ diterapkan sebagai variasi parameter dalam eksperimen. Selain itu, jarak ujung ke kolektor juga divariasikan dengan nilai $3,4,5,6,7$, dan $8 \mathrm{~cm}$. Berdasarkan konfigurasi parameter yang ditetapkan, efek dari proses elektrospinning secara direct deposition yaitu pada perubahan morfologi semikonduktor nanofiber $\mathrm{ZnO}$. Hasil penelitian menunjukkan bahwa debit aliran $4 \mu \mathrm{L} /$ menit dan jarak ujung ke kolektor $8 \mathrm{~cm}$ menghasilkan morfologi dengan diameter kecil dan seragam. Morfologi ini memungkinkan serat nano $\mathrm{ZnO}$ memiliki penyerapan warna dan eksitasi elektron yang lebih baik, dimana berbanding lurus dengan efisiensi tinggi DSSC dengan struktur lapisan ganda. Nilai kinerja untuk debit $4 \mu \mathrm{L} /$ menit adalah 2,39\%, dan untuk jarak ujung jarum ke kolektor sejauh $8 \mathrm{~cm}$ adalah $1,61 \%$.

Keywords: semikonduktor, struktur lapisan ganda, metode direct deposition, sel surya tersensitisasi pewarna (dye-sensitized solar cells-DSSC)

\section{INTRODUCTION:}

Solar cells harvest solar energy that is converted into electrical energy through the photovoltaic process (Grätzel, 2006; Valaski et al., 2007). There have been three generations of solar cells, including silicon solar cells, thin layer type solar cells, and dye-sensitized solar cells (DSSCs) (Ali et al., 2016). The DSSCs are easy to fabricate and have a lower cost than silicon solar cells or thin layer type solar cells (Qadir et al., 2015). The performance of DSSCs, in general, can be characterized by several parameters, namely efficiency value, short-circuit photocurrent density (JSC), fill factor (FF), and open-circuit voltage (VOC). DSSCs are composed of two electrodes, a photoanode electrode and a photo inert counter electrode.

Photoanode electrodes are made of semiconductors that have absorbed dyes and are deposited on transparent conductive oxide. The photo inert counter electrodes are made of a platinum layer superimposed on transparent conductive oxide (Grätzel, 2003; Tobin et al.,
2011). Semiconductors in DSSCs' photoanodes function as converters of photon energy from solar radiation through the process of electron excitation based on the gap of material energy (bandgap) with an average of 1 to $5 \mathrm{eV}$. Some of the photoanode constituent semiconductor materials used for DSSCs are titanium oxide $\left(\mathrm{TiO}_{2}\right)$, zinc oxide ( $\left.\mathrm{ZnO}\right)$, and nickel (II) oxide

(NiO) (Grätzel, 2003; Tobin et al., 2011). TiO2 semiconductors have higher photovoltaic performance in the visible light region compared to $\mathrm{ZnO}$ semiconductors.

However, $\mathrm{ZnO}$ semiconductors have a lower electron charge recombination effect. In increasing electron mobility, nanomaterial engineering improves the properties of semiconductor materials with shapes such as nanoparticles, nanofibers, nanowires, nanorods, nanobelts, nanospirals, nanorings, and nanotubes, because nanomaterial engineering can increase chemical reactivity through the expansion of the relative area. $\mathrm{ZnO}$ and $\mathrm{TiO}_{2}$ semiconductors have gone through a large amount of nanomaterial engineering because they have a better energy gap, i.e., 3.61 and 3.24 
$\mathrm{eV}$, respectively. These gaps can increase the semiconductor absorption of the dye and subsequently the excitation of electrons by photons (Bakr et al., 2019; Khan et al., 2019; Rani and Tripathi, 2015; Suprayogi et al., 2019).

Engineering photoanode layers with $\mathrm{TiO}_{2}$ nanoparticle semiconductors results in a higher surface area than other nanomaterial semiconductors because semiconductor nanoparticles can absorb dye molecules optimally (Chang and Lo, 2010; Seo et al., 2007). However, the morphology of nanoparticles can reduce the mobility of electrons between particles and spread randomly (Mintcheva et al., 2020). By contrast, the semiconductor $\mathrm{ZnO}$ nanofiber layer can bond directly with the substrate and dye to facilitate the mobility of excited electrons. Another advantage of fiber morphology is the effect of scattering photons in a photoanode, thereby increasing electron excitation (Saidin et al., 2017; Sorayani Bafqi et al., 2015). To increase the electron mobility of $\mathrm{TiO}_{2}$ nanoparticle semiconductors, two layers of photoanodes can be engineered as follows: $\mathrm{TiO}_{2}$ nanoparticle semiconductors are deposited with $\mathrm{ZnO}$ nanofiber semiconductors, where the first layer of semiconductor $\mathrm{TiO}_{2}$ nanoparticles functions as a layer of dye loading (DL) and the second layer of semiconductor $\mathrm{ZnO}$ nanofibers functions as a layer of light scattering (LS). The use of a twolayer photoanode could increase the efficiency of DSSCs by up to 2.1 times that of using a single photoanode layer. This is also proportional to the bandgap value of $2.5-3 \mathrm{eV}$. The two-layer photoanode layer arranged to form a sandwich could strengthen the semiconductor bond with the substrate (adhesive properties), as shown in Figure 1 of Appendix (Cao et al., 2017; Ghanbari Niaki et al., 2014; Humayun et al., 2019; Zhou et al., 2019).

Manufacturing modification of the two layers of photoanode can consist of $\mathrm{ZnO}$ semiconductors deposited directly on $\mathrm{TiO}_{2}$ semiconductors. Particulate $\mathrm{TiO}_{2}$ semiconductors can be created using the doctor blade method (Dobrzański et al., 2016), in which a $\mathrm{TiO}_{2}$ paste is deposited on fluorine-doped tin oxide (FTO) glass and sintered. Subsequently, $\mathrm{ZnO}$ nanofiber semiconductors can be obtained from the direct deposition process on FTO glass that has been coated with a $\mathrm{TiO}_{2}$ semiconductor using the electrospinning process. The use of direct deposition methods in the two-layer photoanode engineering is intended to reduce fabrication time and prevent damage to the nanoparticle and nanofiber structures, and can improve DSSCs' performance (Yang et al., 2017). However, the use of the electrospinning process depends on the distribution of molecular weight, the surface viscosity of the solution, and temperature (Panthi et al., 2015; Sorayani Bafqi et al., 2015).

The flow rate and the distance of the tip to the collector in the electrospinning process greatly affect the diameter size in nanofiber morphology. Therefore, this paper investigates the effect of variations in the distance of the tip to the collector and in the discharge of the direct deposition of $\mathrm{ZnO}$ semiconductors on the performance of DSSC double-layer photoanodes. The use of a flow rate of $4 \mu \mathrm{L} / \mathrm{min}$ and a distance of $8 \mathrm{~cm}$ in the electrospinning process were found to provide morphological results with a small and uniform diameter. Semiconductor morphology determines the dye loading value. The amount of dye loading value can affect the DSSC performance value (Alrikabi, 2017; Hekmati et al., 2013; López-Covarrubias et al., 2019). Therefore, flow rates of $3,4,5,6,7$, and $8 \mu \mathrm{L} / \mathrm{min}$ and distances of $3,4,5,6,7$, and $8 \mathrm{~cm}$ were examined.

\section{MATERIALS AND METHODS:}

\subsection{Materials}

In this study, the main reagents used were zinc acetate dihydrate $\left(\left(\mathrm{CH}_{3} \mathrm{COO}\right) 2 \mathrm{Zn} .{ }_{2} \mathrm{H} 2 \mathrm{O}\right.$, Merck) as the main material forming $\mathrm{ZnO}$ semiconductors; polyvinyl alcohol (PVA) $\left(\mathrm{CH}_{2} \mathrm{CH}(\mathrm{OH}) \mathrm{n}, \mathrm{MW}=72,000\right.$, Merck $)$ as a carrier material in the electrospinning process; aquades as a solvent applied to the zinc acetate and PVA to form a homogeneous solution; a glass plate with 28 test working electrodes printed with $\mathrm{TiO}_{2}$ opaque paste $(160 \mathrm{~mm} \times 80 \mathrm{~mm} \times 3.2 \mathrm{~mm})$; synthetic dyes-N719 ([RuL 2 (NCS) $\left.)_{2}\right]: 2 T B A(L=$ 2,2'-bipyridyl-4,4'-dicarboxylic acid; TBA = tetra-nbutylammonium)) and lodide (I3-) EL-HPE electrolyte solution (Hongsith et al., 2015).

\subsection{Fabrication of $\mathrm{ZnO}$ Nanofibers}

The addition of precursor solutions was used to produce the morphology of the nanofibers. The precursor solution was prepared using $2 \mathrm{~g}$ of PVA (Merck, MW = 72,000) mixed with $20 \mathrm{ml}$ of $\mathrm{H}_{2} \mathrm{O}(\mathrm{pH}=7)$. The homogenization process was carried out by stirring for $4 \mathrm{~h}$ at a 70 ${ }^{\circ} \mathrm{C}$ solution temperature. The $\mathrm{Zn}(\mathrm{Ac})_{2}$ solution was synthesized using $2 \mathrm{~g}$ of zinc acetatedihydrate $\left(\left(\mathrm{CH}_{3} \mathrm{COO}\right) 2 \mathrm{Zn} .2 \mathrm{H}_{2} \mathrm{O}\right.$, Merck), 
and $8 \mathrm{ml}$ of $\mathrm{H}_{2} \mathrm{O}$, and then the homogenization process was carried out by stirring for $1 \mathrm{~h}$ while keeping the solution at $70{ }^{\circ} \mathrm{C}$. Subsequently, the homogenization process between the PVA solution and $\mathrm{Zn}(\mathrm{Ac})_{2}$ was carried out in a ratio of $4: 1 \mathrm{wt} \%$ at $70{ }^{\circ} \mathrm{C}$ for $8 \mathrm{~h}$. The entire solution was mixed in a closed container using a magnetic stirrer.

Following the above, the $\mathrm{PVA} / \mathrm{Zn}(\mathrm{Ac})_{2}$ solution was left in a closed room at room temperature for $24 \mathrm{~h}$ so that the foam formed could be lost. The result is a PVA/Zn(Ac) $)_{2}$ solution, which is used to produce the $\mathrm{ZnO}$ nanofiber fibers using an electrospinning machine (Zhou et al., 2019).

The PVA/Zn(Ac) $)_{2}$ solution was used to form $\mathrm{ZnO}$ nanofibers on the $\mathrm{TiO}_{2} / \mathrm{ZnO}$ doublelayer DSSCs through an electrospinning process (Katoch et al., 2014). As much as $1 \mathrm{~mL}$ of the solution was injected into a syringe pump and connected to the electrospinning machine at the Nanobioenergy Lab, Universitas Sebelas Maret Surakarta, as shown in Figure 2 of Appendix. Electrospinning machine specifications: collector; voltage power supply: $15 \mathrm{kV}$; injection pump tip distance to the collector: 10-200 mm; injection pump solution output: $2.237 \mathrm{ml} / \mathrm{h}$. The tip on the syringe pump was connected to a high voltage positive terminal at varying distances $(3,4,5,6$, 7 , and $8 \mathrm{~cm}$ ) located horizontally relative to the collector plate of the fluorine-doped tin oxide glass deposited with $\mathrm{TiO}_{2}$ with negative terminals using the direct deposition method. The flow rate of the solution through the needle was varied $(3$, $4,5,6,7$, and $8 \mu \mathrm{L} / \mathrm{min}$ ) based on the rate at the electrospinning machine. The fluorine-doped tin oxide glass deposited with $\mathrm{TiO}_{2}$ nanoparticles and $\mathrm{ZnO}$ nanofibers was sintered at a temperature of $500{ }^{\circ} \mathrm{C}$ with a retention time of $1 \mathrm{~h}$ using a Digital Muffle Furnace model XD-1700M. The semiconductor deposition sintering results can be used as double-layer DSSC photoanodes (Hegazy et al., 2016).

\subsection{Assembling double-layer DSSCs}

Double-layer DSSC photoanodes were soaked with synthetic dye N719 ([RuL $\left.(\mathrm{NCS})_{2}\right]$ : 2TBA ( $\mathrm{L}=2,2$ '-bipyridyl-4,4'-dicarboxylic acid; TBA = tetra-n-butylammonium) manufactured by Dyesol that was dissolved with a sensitizer solution. The sensitizer solution was prepared by dissolving $0.02 \mathrm{~g} \mathrm{~N} 719$ powder into $100 \mathrm{ml}$ of ethanol. The resulting double-layer DSSC photoanodes were immersed in N719 dye for 24 h. The double-layered photoanode can absorb the solution completely (Sakai et al., 2013). The results of the DSSC double-layer photoanode immersion were combined and bonded with a perforated counter electrode. Subsequently, ELHPE lodide $\left({ }^{3-}\right)$ solution manufactured by Dyesol, which was used as an electrolyte, was injected through a hole in the counter electrode and covered with a Dyesol plaster. The FTO substrate components, colorants, electrolytes, and counter electrodes form unified DSSCs (Kouhestanian et al., 2016; Wei and Hu, 2015).

\subsection{Testing}

DSSCs performance was examined using scanning electron microscopy (SEM) to determine the morphology and size of semiconductor nanofibers; absorbance testing with a UV 1800 UV-VIS spectrophotometer was used to measure the bandgap energy value using Tauc's plot method, as shown in Equation 1 (Alrikabi, 2017; Firdaus et al., 2012). The bandgap energy function is the value of VOC, as shown in Equation 2 (Bakr et al., 2019); the dyeloading ability of each sample was measured using the desorption method and the LambertBeer equation, which tests the solution's absorbance, as shown in Equation 3 (Asib et al., 2018).

$$
\begin{aligned}
& E=h v=\frac{h \cdot c}{\lambda} \\
& V O C=\frac{E_{C B}}{e}+\frac{k_{B} T}{e} \ln \left(\frac{n}{N_{C B}}\right)-E_{\text {redox }} \\
& A=\text { E.cl }
\end{aligned}
$$

The performance of the DSSCs was tested using a Solar Simulator Machine with a light intensity of $100 \mathrm{~mW} / \mathrm{cm}^{2}$ and a surface area of $1 \mathrm{~cm}^{2}$. The DSSC performance was evaluated by measuring the following: open-circuit photovoltage (VOC), photocurrent voltage curve (IV curve), fill factor (FF), short-circuit photocurrent density (JSC), and efficiency (n). Voltage and current curves were obtained from measurements' results, as shown in Figure 3 of Appendix (Humayun et al., 2019).

In the voltage-current curve (IV), was a maximum power point (PMAX) could be observed, which is the product of the maximum current and voltage. The fill factor (FF) value arises from a comparison between maximum power (Pmax) and the multiplication of ISC and VOC values, as shown in Equation 4. The 
DSSCs' efficiency was obtained from the ratio between maximum power (Pmax) and light emitted in the solar cell (Plight). Light emission produces power, which is the result of the multiplication of the intensity of sunlight with the area of the active region, so that solar cell efficiency was obtained as shown in Equation 5 (Chou et al., 2007; Hongsith et al., 2015; Junger et al., 2018).

$$
\begin{aligned}
& F F=\frac{V_{M A X} \times I_{M A X}}{I_{S C} \times V_{O C}} \\
& \eta=\frac{P_{M A X}}{P_{\text {light }}}=\frac{P_{M A X}}{I x A}=\frac{I_{S C} \times V_{O C} \times F F}{I x A}
\end{aligned}
$$

\section{RESULTS AND DISCUSSION:}

\subsection{Analysis of Scanning Electron Microscope (SEM) Results}

\subsubsection{Variation of Flow Rate}

Figure 4 in Appendix shows the morphological forms of $\mathrm{ZnO}$ nanofiber semiconductors on double-layer DSSCs fabricated with various flow rates using the electrospinning process. It can be seen that lower flow rates produced more uniform shapes and diameters of the nanofibers. This is due to the fact that the lower flow rate emitted smaller solution bubbles through the injection pump tip onto the electrospinning machine. The emitted bubbles showed better stretching characteristics for the same electrostatic field. Additionally, faster stretches make it easier to dry and form fibers in the collector (Benehkohal and Demopoulos, 2012; Dissanayake et al., 2016).

Solution which has flow rate of $4 \mu \mathrm{L} / \mathrm{min}$ in the fabrication process, causes smaller and more uniform nanofiber diameter. This was influenced by operational conditions (solution rate, tip distance to the collector, potential difference, and syringe needle size) and the solution (viscosity, conductivity, and surface tension). Because in this study the flow rate was varied and all other conditions were equal, the differences in diameter can be attributed to changes in the flow rate in the electrospinning process. As can be seen in Table 1 of Appendix, the flow rates of $4 \mu \mathrm{L} / \mathrm{min}$ produced an average diameter that was 118.335 $\mathrm{nm}$ smaller than the flow rates of $3,5,6,7$, and 8 $\mu \mathrm{L} / \mathrm{min}$. The smaller and more uniform the diameter of the nanofiber morphology, the more active will the surface area be in the process of absorbing the dye, which will, in turn, increase the absorption of light (Firdaus et al., 2012; Grätzel, 2003; López-Covarrubias et al., 2019; Saidin et al., 2017).

\subsubsection{Variations in Tip Distance to Collectors}

SEM images of the $\mathrm{ZnO}$ nanofiber semiconductors on double-layer DSSCs that resulted from varying the distance between the tip and the collector during the electrospinning process are shown in Figure 5 of Appendix. All of the conditions of the fabrication of the $\mathrm{ZnO}$ semiconductors using the electrospinning process were constant except for the tip distance to the collector, which was is varied. The figure shows that the larger the distance between the tip and the collector was, the more uniform were the results' morphological shape and size. This is because a closer distance of the tip to the collector causes the jet/whip to accelerate while the solution bubbles stick to the collector and turn into fibers. The overlapping fibers then do not stretch and may evaporate. Therefore, with closer distances, the resultant nanofiber had an irregular size and shape (Firdaus et al., 2012; Saidin et al., 2017).

As shown in Table 2 of Appendix, using a tip-to-collector distance of $8 \mathrm{~cm}$ resulted in an average diameter that was smaller than the other variations by $92.70 \mathrm{~nm}$. The small size of the nanofiber expanded the surface of the semiconductor, thus increasing the absorption of dyes. A high absorption value of the dye facilitates the entry of light and thus the electron flow, as observed from the performance of DSSCs (Sorayani Bafqi et al., 2015).

\subsection{Characterization of Light Absorbance and Transmittance}

The absorbance value of the DSSCs was obtained using the desorption method by releasing the bonds between the semiconductor and the absorbed dye using a base solvent. In this study, the double-layer DSSC photoanode was soaked in $8 \mathrm{ml}$ alkaline solution $(0.1 \mathrm{M}$ $\mathrm{NaOH}$ ) for $1 \mathrm{~h}$. The bond between the semiconductor surface and the carboxylic acid could thus be broken, then the $\mathrm{OH}^{-}$ions bonded to the dye molecules. Hence, the dye was separated from the semiconductor entirely. The released dye solution was tested for its absorbance value using UV-VIS (Asib et al., 2018; Marimuthu et al., 2018). 


\subsubsection{Flow Rate Variation}

Figure $6 a$ of Appendix shows the magnitude of the absorbance value for each flow rate variation in the electrospinning process. It can be seen that based on the trend of the N719 dye, at a wavelengths of $450-550 \mathrm{~nm}$, the use of $4 \mu \mathrm{L} / \mathrm{min}$ discharge had a higher absorbance value compared to other flow rate variations (Alrikabi, 2017). This is related to the shape and size of the morphology that resulted from the flow rate of $4 \mu \mathrm{L} / \mathrm{min}$, which was uniform and had a smaller average diameter compared to other flow rates. As a result, it had a better dye loading ability, which was $1.25 \times 10^{-7} \mathrm{~mol} / \mathrm{cm}^{2}$. A high absorbance value increases the current density (JSC), which affects the efficiency of the DSSCs (Lee et al., 2015). As the dye trend we used is at a wavelengths of $450-550 \mathrm{~nm}$, the transmittance value is inversely proportional to the absorbance value (Marimuthu et al., 2017). As shown in Figure $6 \mathrm{~b}$ of Appendix, the use of $4 \mu \mathrm{L} / \mathrm{min}$ discharge resulted in the lowest transmittance value. This is because of the large absorption ability of the dye using a discharge variation of 4 $\mu \mathrm{L} / \mathrm{min}$.

\subsubsection{Tip Distance to Collector Variations}

Regarding tip-to-collector distance variations, the usage of a distance of $8 \mathrm{~cm}$ resulted in the double-layer DSSCs with the highest absorbance values at wavelengths of $450-550 \mathrm{~nm}$. As shown in Figure 7a of Appendix, the farther the tip's distance to the collector, the higher the absorbance value that was obtained. Based on the double-layer photoanode's characteristics, a high absorbance value indicated a higher light absorption ability. This was also corroborated by the large value of dye loading calculated according to the Lambert-Beer equation. The usage of an $8 \mathrm{~cm}$ tip-to-collector distance resulted in a dye loading value of $1.25 \times$ $10^{-7} \mathrm{~mol} / \mathrm{cm}^{2}$, thus increasing the amount of electric current received from the DSSCs (Kabir et al., 2019; Marimuthu et al., 2017). The light transmitted from or exited by the photoanode was identified through the results of the transmittance test. The lower the transmittance value, the less light which came out. As can be seen in Figure $7 \mathrm{~b}$ of Appendix, the use of an $8 \mathrm{~cm}$ tip-to-collector distance resulted in the lowest transmittance value at the $450-550 \mathrm{~nm}$ wavelengths. This indicates that the $\mathrm{ZnO}$ semiconductor nanofiber produced by direct deposition using the electrospinning process helped the dye loading by blocking the amount of light that came out.

\subsection{Band Gap Testing}

The bandgap energy value was determined through absorbance spectrum testing in ultraviolet rays and visible light, i.e., the wavelengths of 200 to $800 \mathrm{~nm}$. Through the graph derived by Tauc plot method, the value of the bandgap was obtained by extrapolating the linear line of the curve formed by ( $\alpha . h v) 1 / r$ to $h v$, where $\alpha$ is the absorbance coefficient and $h v$ is the photon energy. Figures $8 a$ and $8 b$ of Appendix show the bandgap values for each variation. The results show that the larger the tipto-collector distance and the smaller the flow rate, the lower the obtained bandgap value. A decrease in the value of the bandgap is an indication of a shrinking semiconductor size. This allows for easier electron excitation when obtaining energy from outside (Bakr et al., 2019; Ghanbari Niaki et al., 2014).

\subsection{Performance of DSSCs}

\subsubsection{Flow Rate Variation}

The curve in Figure 9a of Appendix indicates the photocurrent vs. photovoltage (IV) density for each DSSCs variation of discharge with an intensity of $100 \mathrm{~mW} / \mathrm{cm}^{2}$. Table 3 of Appendix illustrates the performance of DSSCs according to VOC, JSC, FF, and efficiency values for the discharge variations. The results show that the morphological changes to the $\mathrm{ZnO}$ nanofiber semiconductors had a large influence on JSC and a small effect on the VOC of DSSCs. This shows that the $4 \mu \mathrm{L} / \mathrm{min}$ precursor discharge in the nanofiber electrospinning process produced a small nanofiber size and the maximum electrical conductivity. Higher conductivity values were found to reduce electrical resistance in DSSCs (Seo et al., 2007). With a greater dye loading ability for light absorption and optimal electrical conductivity, the variation of the $4 \mu \mathrm{L} / \mathrm{min}$ precursor discharge had the maximum value of DSSCs efficiency among the variations examined. It can be seen that the discharge of $4 \mu \mathrm{L} / \mathrm{min}$ had the highest efficiency of DSSCs at $2.39 \%$. VOC, JSC, and FF values were $0.58 \mathrm{~V}, 9.14 \mathrm{~mA} / \mathrm{cm}^{2}$, and $45.18 \%$, respectively.

\subsubsection{Tip Distance to Collector Variations}

The performance characteristics of the double-layer photoanodes as a function of variation of tip-to-collector distance can be seen in Figure $9 \mathrm{~b}$ and Table 4 of Appendix. DSSCs with direct deposition of $\mathrm{ZnO}$ nanofibers with a distance of $8 \mathrm{~cm}$ from tip to the collector had the highest photovoltaic conversion efficiency. As 
seen from the SEM test results, the $8 \mathrm{~cm}$ tip-tocollector distance resulted in the smallest nanofiber size. The small $\mathrm{ZnO}$ nanofiber semiconductor diameter increased the DSSCs' photovoltaic performance due to the higher surface area for absorbing dye molecules (dye loading), resulting in higher light absorption (Hekmati et al., 2013; Ramli et al., 2019; Sorayani Bafqi et al., 2015). It can be seen that the $8 \mathrm{~cm}$ tip-to-collector distance resulted in the highest efficiency of DSSCs at $1.61 \%$. VOC, JSC, and $F F$ values were $0.56 \mathrm{~V}, 6.41 \mathrm{~mA} / \mathrm{cm}^{2}$, and $44.920 \%$, respectively.

\section{CONCLUSIONS:}

Double-layer $\mathrm{TiO}_{2}-\mathrm{ZnO}$ DSSCs were obtained using nanofiber $\mathrm{ZnO}$ semiconductors deposited directly on fluorine-doped tin oxide (FTO) glass coated with a $\mathrm{TiO}_{2}$ nanoparticle semiconductor using an electrospinning machine. The use of a solution flow rate of $4 \mu \mathrm{L} / \mathrm{min}$ and a distance of $8 \mathrm{~cm}$ from the tip of the needle to the collector in the direct deposition process using an electrospinning machine produced better nanofibers than other variations, whose morphology had a small and uniform diameter of 118.35 and $85.6 \mathrm{~nm}$, with a dye loading value of $1.25 \times 10^{-7} \mathrm{~mol} / \mathrm{cm}^{2}$. The performance value for the discharge of $4 \mu \mathrm{L} / \mathrm{min}$ was $2.39 \%$, and for the $8 \mathrm{~cm}$ tip-to-collector distance the value was $1.61 \%$.

\section{ACKNOWLEDGMENTS:}

This work was partially supported by a PDUPT grant from the Ministry of Research, Technology, and Higher Education, the Republic of Indonesia, with contract number 112/UN27.21/ HK/2020 for FY 2020.

\section{REFERENCES:}

1. Ali, N., Hussain, A., Ahmed, R., Wang, M. K., Zhao, C., Haq, B. U., and Fu, Y. Q. (2016). Advances in nanostructured thin-film materials for solar cell applications. Renewable and Sustainable Energy Reviews, 59, 726-737. https://doi.org/10.1016/j.rser.2015.12.268

2. Alrikabi, A. (2017). Theoretical study of the design dye-sensitivity for usage in the solar cell device. Results in Physics, 7(July), 4359-4363.

https://doi.org/10.1016/j.rinp.2017.07.022
3. Asib, N. A. M., Aadila, A., Afaah, A. N., Rusop, M., and Khusaimi, Z. (2018). Lowtemperature growth of $\mathrm{ZnO}$ nanorods array via solution-immersion on $\mathrm{TiO} 2$ seed layer. AIP Conference Proceedings, 1963. https://doi.org/10.1063/1.5036904

4. Bakr, Z. H., Wali, Q., Yang, S., Yousefsadeh, M., Padmasree, K. P., Ismail, J., Ab Rahim, M. H., Yusoff, M. M., and Jose, R. (2019). Characteristics of ZnO-SnO 2 Composite Nanofibers as a Photoanode in DyeSensitized Solar Cells. Industrial and Engineering Chemistry Research, 58(2), 643-653.

https://doi.org/10.1021/acs.iecr.8b03882

5. Benehkohal, N. P., and Demopoulos, G. P. (2012). Green Preparation of TiO $2-\mathrm{ZnO}$ Nanocomposite Photoanodes by Aqueous Electrophoretic Deposition. 159(5), 602-610. https://doi.org/10.1149/2.016206jes

6. Cao, F., Tian, W., Gu, B., Ma, Y., Lu, H., and $\mathrm{Li}$, L. (2017). High-performance UV-vis photodetectors based on electrospun $\mathrm{ZnO}$ nanofiber-solution processed perovskite hybrid structures. Nano Research, 10(7), 2244-2256. https://doi.org/10.1007/s12274016-1413-2

7. Chang, H., and Lo, Y. J. (2010). Pomegranate leaves and mulberry fruit as natural sensitizers for dye-sensitized solar cells. Solar Energy, 84(10), 1833-1837. https://doi.org/10.1016/j.solener.2010.07.009

8. Chou, T. P., Zhang, Q., Fryxell, G. E., and Cao, G. (2007). Hierarchically structured $\mathrm{ZnO}$ film for dye-sensitized solar cells with enhanced energy conversion efficiency. Advanced Materials, 19(18), 2588-2592. https://doi.org/10.1002/adma.200602927

9. Dissanayake, S. S., Dissanayake, M. A. K. L., Seneviratne, V. A., Senadeera, G. K. R., and Thotawattage, C. A. (2016). Performance of Dye-Sensitized Solar Cells Fabricated with Electrospun Polymer Nanofiber Based Electrolyte. Materials Today: Proceedings, 3(Icfmd 2015), S104S111. https://doi.org/10.1016/j.matpr.2016.01.014

10. Dobrzański, L. A., Mucha, A., Prokopowicz, M. P. vel, Szindler, M., Drygała, A., and Lukaszkowicz, K. (2016). Characteristics of dye-sensitized solar cells with carbon 
nanomaterials. Materiali in Tehnologije, 50(5), 649-654.

https://doi.org/10.17222/mit.2014.134

11. Firdaus, C. M., Shah Rizam, M. S. B., Rusop, M., and Rahmatul Hidayah, S. (2012). Characterization of $\mathrm{ZnO}$ and $\mathrm{ZnO}$ : TiO2 thin films prepared by sol-gel sprayspin coating technique. Procedia Engineering, 41(Iris), 1367-1373. https://doi.org/10.1016/j.proeng.2012.07.323

12. Ghanbari Niaki, A. H., Bakhshayesh, A. M., and Mohammadi, M. R. (2014). Double-layer dye-sensitized solar cells based on Zn-doped $\mathrm{TiO} 2$ transparent and light scattering layers: Improving electron injection and light scattering effect. Solar Energy, 103, 210222.

https://doi.org/10.1016/j.solener.2014.01.041

13. Grätzel, M. (2003). Dye-sensitized solar cells. Journal of Photochemistry and Photobiology C: Photochemistry Reviews, 4(2),

https://doi.org/10.1016/S13895567(03)00026-1

14. Grätzel, M. (2006). Photovoltaic performance and long-term stability of dye-sensitized meosocopic solar cells. Comptes Rendus Chimie, 9(5-6), 578-583. https://doi.org/10.1016/j.crci.2005.06.037

15. Hegazy, A., Kinadjian, N., Sadeghimakki, B., Sivoththaman, S., Allam, N. K., and Prouzet, E. (2016). TiO2 nanoparticles optimized for photoanodes tested in large area Dyesensitized solar cells (DSSC). Solar Energy Materials and Solar Cells, 153, 108-116. https://doi.org/10.1016/j.solmat.2016.04.004

16. Hekmati, A. H., Rashidi, A., Ghazisaeidi, R., and Drean, J. Y. (2013). Effect of needle length, electrospinning distance, and solution concentration on morphological properties of polyamide- 6 electrospun nanowebs. Textile Research Journal, 83(14), 1452-1466. https://doi.org/10.1177/0040517512471746

17. Hongsith, K., Hongsith, N., Wongratanaphisan, D., Gardchareon, A., Phadungdhitidhada, S., and Choopun, S. (2015). Efficiency Enhancement of ZnO Dyesensitized Solar Cells by Modifying Photoelectrode and Counterelectrode. In Energy Procedia (Vol. 79). Elsevier B.V. https://doi.org/10.1016/j.egypro.2015.11.503
18. Humayun, M., Zheng, Z., Fu, Q., and Luo, W. (2019). Photodegradation of 2,4dichlorophenol and rhodamine B over n-type $\mathrm{ZnO} /$ p-type $\mathrm{BiFeO} 3$ heterojunctions: detailed reaction pathway and mechanism. Environmental Science and Pollution Research, 26(17), 17696-17706. https://doi.org/10.1007/s11356-019-05079-0

19. Junger, I. J., Wehlage, D., Böttjer, R., Grothe, T., Juhász, L., Grassmann, C., Blachowicz, T., and Ehrmann, A. (2018). Dye-sensitized solar cells with electrospun nanofiber mat-based counter electrodes. Materials, 11(9). https://doi.org/10.3390/ma11091604

20. Kabir, F., Bhuiyan, M. M. H., Hossain, M. R., Bashar, H., Rahaman, M. S., Manir, M. S., Ullah, S. M., Uddin, S. S., Mollah, M. Z. I., Khan, R. A., Huque, S., and Khan, M. A. (2019). Improvement of efficiency of DyeSensitized Solar Cells by optimizing the combination ratio of Natural Red and Yellow dyes. Optik, 179(October 2018), 252-258. https://doi.org/10.1016/j.ijleo.2018.10.150

21. Katoch, A., Kim, J. H., and Kim, S. S. (2014). $\mathrm{TiO} 2 / \mathrm{ZnO}$ inner/outer double-layer hollow fibers for improved detection of reducing gases. ACS Applied Materials and Interfaces, 6(23), 21494-21499. https://doi.org/10.1021/am506499e

22. Khan, M. I., Saleem, M., Rehman, S. U., Ali, S. S., Qadri, M. U., Ahmed, N., Javed, M. S., and Iqbal, J. (2019). Stacked Layer Effect of $\mathrm{ZnO} / \mathrm{TiO} 2$ on the Efficiency of DyeSensitized Solar Cells . Journal of Nanoelectronics and Optoelectronics, 14(2), 291-296.

https://doi.org/10.1166/jno.2019.2493

23. Kouhestanian, E., Mozaffari, S. A., Ranjbar, M., SalarAmoli, H., and Armanmehr, M. H. (2016). Electrodeposited $\mathrm{ZnO}$ thin film as an efficient alternative blocking layer for $\mathrm{TiCl} 4$ pre-treatment in TiO2-based dye-sensitized solar cells. Superlattices and Microstructures, $96, \quad 82-94$. https://doi.org/10.1016/j.spmi.2016.05.012

24. Lee, J. S., Kim, K. H., Kim, C. S., and Choi, H. W. (2015). Synergistic effect of TiCl4-ZnO treated $\mathrm{TiO} 2$ nanotubes in dye-sensitized solar cell. Japanese Journal of Applied Physics, 54(6). https://doi.org/10.7567/JJAP.54.06FK02 
25. López-Covarrubias, J. G., Soto-Muñoz, L., Iglesias, A. L., and Villarreal-Gómez, L. J. (2019). Electrospun nanofibers applied to dye solar sensitive cells: A review. Materials, 12(19), https://doi.org/10.3390/ma12193190

26. Marimuthu, T., Anandhan, N., and Thangamuthu, R. (2018). Electrochemical synthesis of one-dimensional $\mathrm{ZnO}$ nanostructures on $\mathrm{ZnO}$ seed layer for DSSC applications. Applied Surface Science, 428, 385-394.

https://doi.org/10.1016/j.apsusc.2017.09.116

27. Marimuthu, T., Anandhan, N., Thangamuthu, R., and Surya, S. (2017). Facile growth of $\mathrm{ZnO}$ nanowire arrays and nanoneedle arrays with flower structure on $\mathrm{ZnO}-\mathrm{TiO} 2$ seed layer for DSSC applications. Journal of Alloys and Compounds, 693, 1011-1019. https://doi.org/10.1016/j.jallcom.2016.09.260

28. Mintcheva, N., Yamaguchi, S., and Kulinich, S. A. (2020). Hybrid TiO2-ZnO nanomaterials prepared using laser ablation in liquid. Materials, 13(3), 11-15. https://doi.org/10.3390/ma13030719

29. Panthi, G., Park, M., Kim, H. Y., Lee, S. Y., and Park, S. J. (2015). Electrospun ZnO hybrid nanofibers for photodegradation of wastewater containing organic dyes: A review. Journal of Industrial and Engineering Chemistry, 21, 26-35. https://doi.org/10.1016/j.jiec.2014.03.044

30. Qadir, M. B., Sun, K. C., Sahito, I. A., Arbab, A. A., Choi, B. J., Yi, S. C., and Jeong, S. H. (2015). Composite multi-functional over layer: $A$ novel design to improve the photovoltaic performance of DSSC. Solar Energy Materials and Solar Cells, 140, 141149.

https://doi.org/10.1016/j.solmat.2015.04.011

31. Ramli, N. F., Fahsyar, P. N. A., Ludin, N. A., Teridi, M. A. M., Ibrahim, M. A., Zaidi, S. H., and Sepeai, S. (2019). Compatibility between compact and mesoporous $\mathrm{TiO} 2$ layers on the optimization of photocurrent density in photoelectrochemical cells. Surfaces and Interfaces, 17(March), 100341. https://doi.org/10.1016/j.surfin.2019.100341

32. Rani, M., and Tripathi, S. K. (2015). A Comparative Study of Nanostructured TiO2, $\mathrm{ZnO}$ and Bilayer TiO2/ZnO Dye-Sensitized
Solar Cells. Journal of Electronic Materials, 44(4), $1151-1159$. https://doi.org/10.1007/s11664-015-3636-5

33. Saidin, N. U., Choo, T. F., Kok, K. Y., Yusof, M. R., and Ng, I. K. (2017). Fabrication and characterization of $\mathrm{ZnO}$ nanofibers by electrospinning. Materials Science Forum, 888 MSF, 309-313. https://doi.org/10.4028/www.scientific.net/MS F.888.309

34. Sakai, N., Miyasaka, T., and Murakami, T. N. (2013). Efficiency enhancement of $\mathrm{ZnO}$ based dye-sensitized solar cells by lowtemperature $\mathrm{TiCl} 4$ treatment and dye optimization. In Journal of Physical Chemistry C (Vol. 117, Issue 21, pp. 1094910956). https://doi.org/10.1021/jp401106u

35. Seo, J. W., Chung, H., Kim, M. Y., Lee, J., Choi, I. H., and Cheon, J. (2007). Development of water-soluble singlecrystalline $\mathrm{TiO} 2$ nanoparticles for photocatalytic cancer-cell treatment. In Small (Vol. 3, Issue 5, pp. 850-853). https://doi.org/10.1002/smll.200600488

36. Sorayani Bafqi, M. S., Bagherzadeh, R., and Latifi, M. (2015). Fabrication of composite PVDF-ZnO nanofiber mats by electrospinning for energy scavenging application with enhanced efficiency. Journal of Polymer Research, 22(7), 1-9. https://doi.org/10.1007/s10965-015-0765-8

37. Suprayogi, T., Masrul, M. Z., Diantoro, M., Taufiq, A., Fuad, A., and Hidayat, A. (2019). The Effect of Annealing Temperature of $\mathrm{ZnO}$ Compact Layer and $\mathrm{TiO} 2$ Mesoporous on Photo-Supercapacitor Performance. IOP Conference Series: Materials Science and Engineering, https://doi.org/10.1088/1757$899 X / 515 / 1 / 012006$

38. Tobin, L. L., O'Reilly, T., Zerulla, D., and Sheridan, J. T. (2011). Characterising dyesensitised solar cells. Optik, 122(14), 12251230.

https://doi.org/10.1016/j.ijleo.2010.07.028

39. Valaski, R., Canestraro, C. D., Micaroni, L., Mello, R. M. Q., and Roman, L. S. (2007). Organic photovoltaic devices based on polythiophene films electrodeposited on FTO substrates. Solar Energy Materials and Solar Cells, $\quad 91(8)$,

684-688. 
https://doi.org/10.1016/j.solmat.2006.12.005

40. Wei, W., and Hu, Y. H. (2015). Synthesis of carbon nanomaterials for dye-sensitized solar cells. In International Journal of Energy Research (Vol. 39, Issue 6, pp. 842-850). https://doi.org/10.1002/er.3312

41. Yang, M., Dong, B., Yang, X., Xiang, W., Ye, Z., Wang, E., Wan, L., Zhao, L., and Wang, S. (2017). TiO2 nanoparticle/nanofiber-ZnO photoanode for the enhancement of the efficiency of dye-sensitized solar cells. RSC Advances, 7(66),

41738-41744. https://doi.org/10.1039/c7ra07644d

42. Zhou, C., Wang, H., Huang, T., Zhang, $X$., Shi, Z., Zhou, L., Lan, Y., and Tang, G. (2019). High-Performance TiO2/ZnO Photoanodes for CdS Quantum DotSensitized Solar Cells. Journal of Electronic Materials, 48(11), 7320-7327. https://doi.org/10.1007/s11664-019-07536-5

\section{APPENDIX}

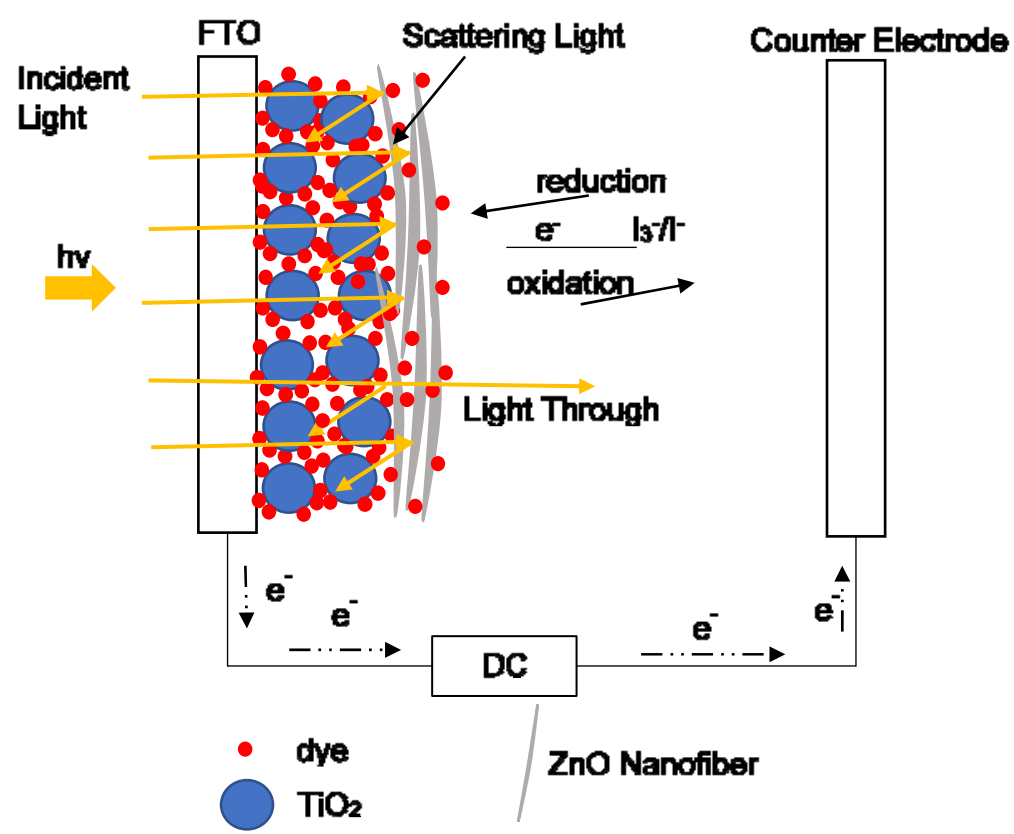

Figure 1. DSSCs double-layer photoanode structure. 


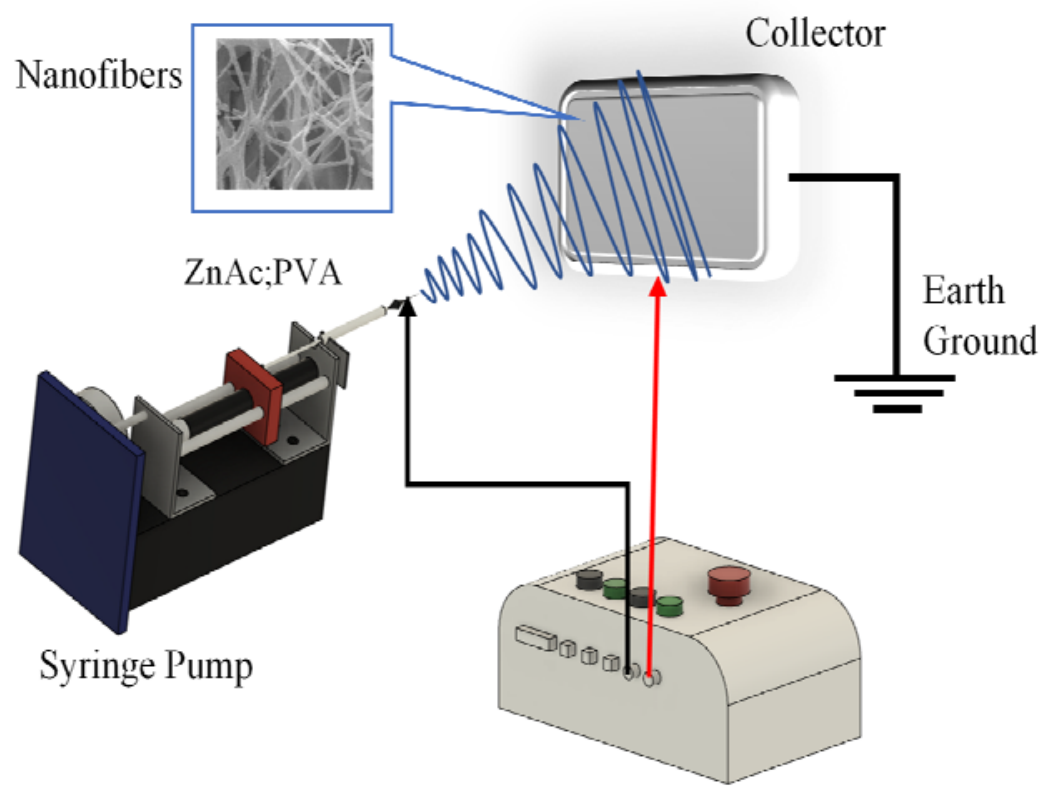

High Voltage Power Supply

(a)

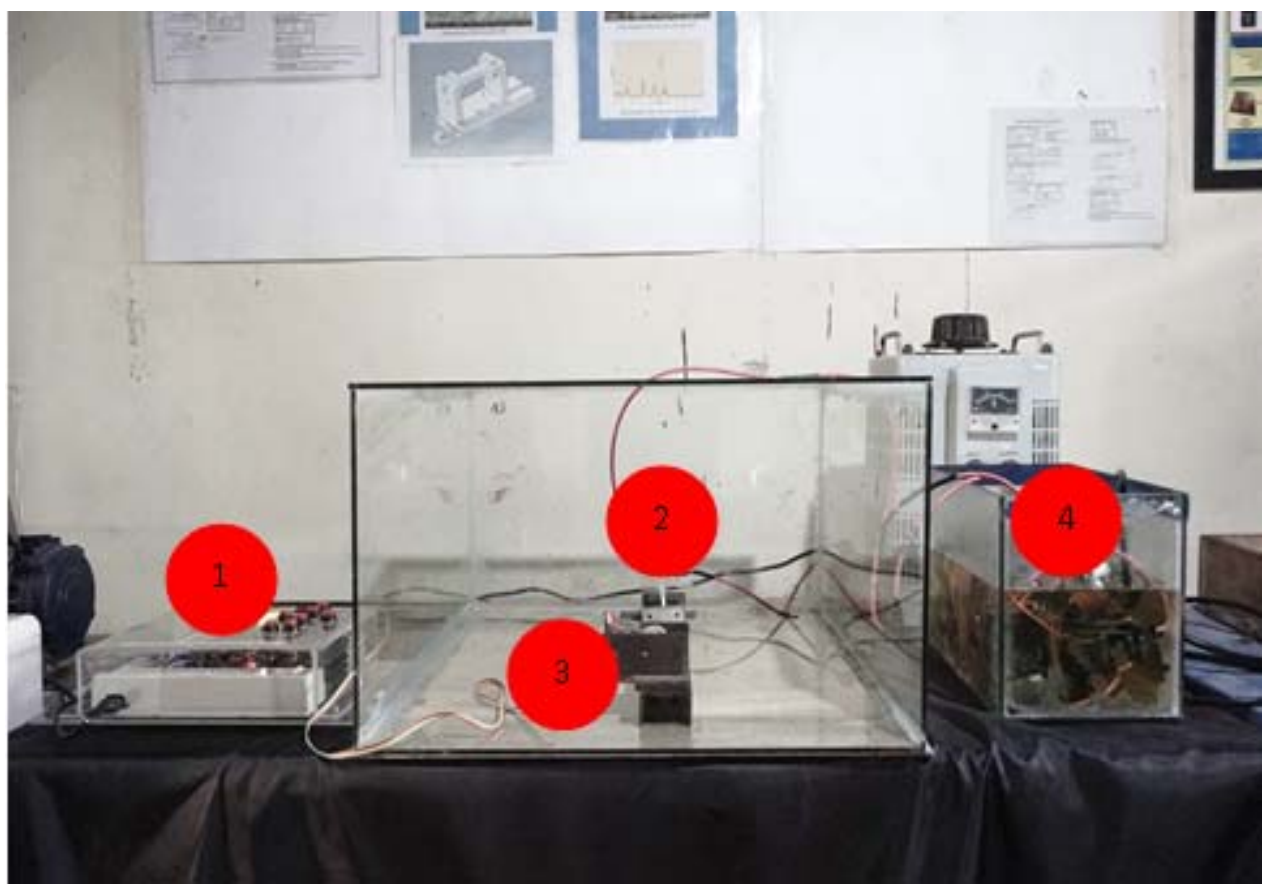

Note:

1. Modul Electrospinning Machine

2. Collector

3. Syringe Pump

4. High Voltage Power Supply

(b)

Figure 2. (a) Scheme process (b) electrospinning machine. 


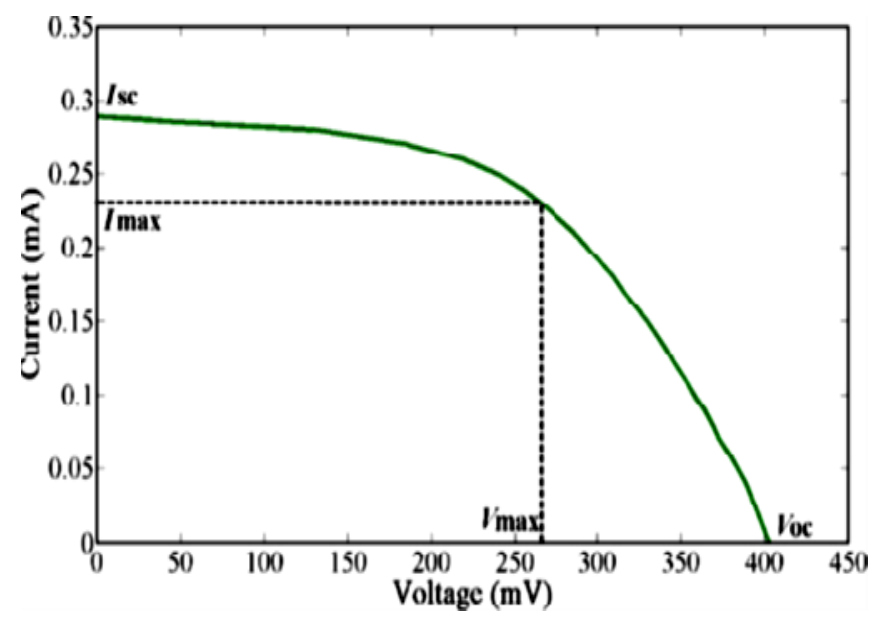

Figure 3. Voltage-current curves (IV curves) found on DSSCs (Tobin et al., 2011)

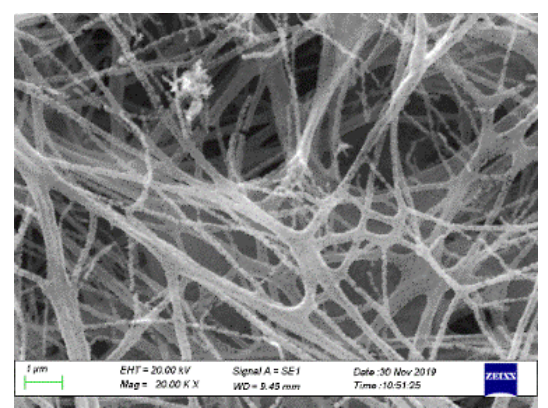

(a)

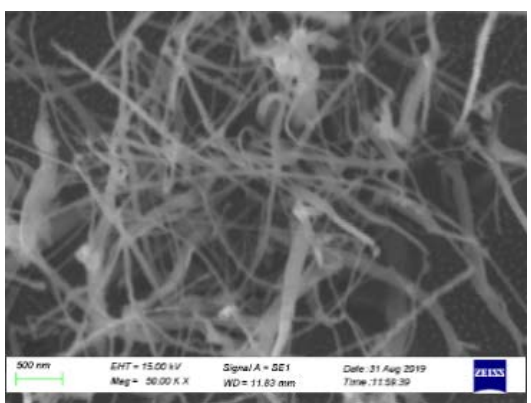

(d)

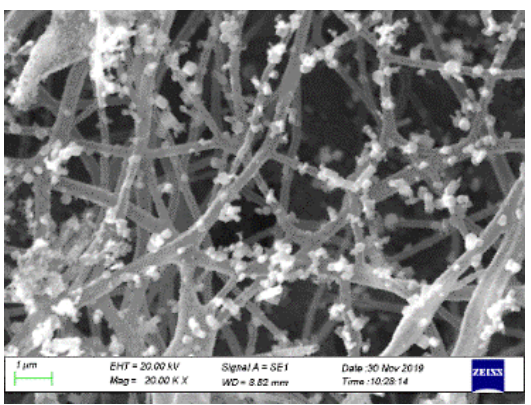

(b)

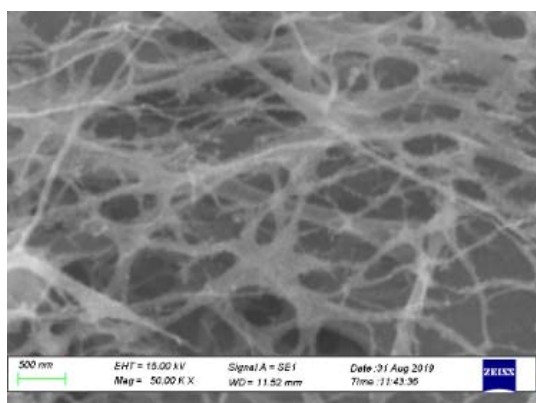

(e)

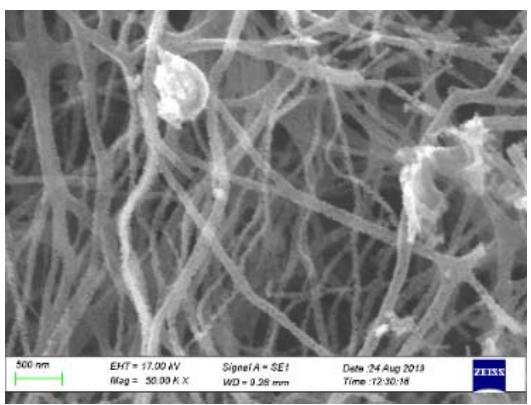

(c)

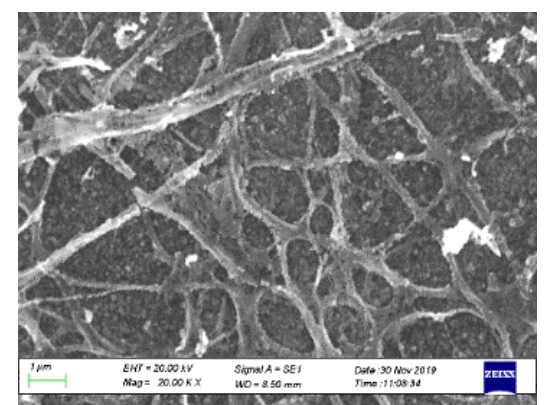

(f)

Figure 4. Semiconductor SEM photo results for variations of (a) $3 \mu \mathrm{L} / \mathrm{min}$ (b) $4 \mu \mathrm{L} / \mathrm{min}$ (c) $5 \mu \mathrm{L} / \mathrm{min}$ (d) $6 \mu \mathrm{L} / \min (e) 7 \mu \mathrm{L} / \mathrm{min}$ (f) $8 \mu \mathrm{L} / \mathrm{min}$. 


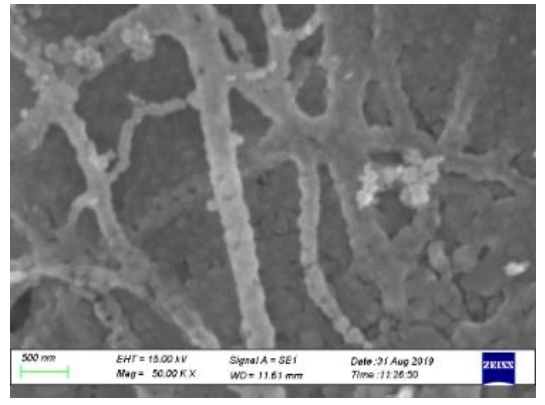

(a)

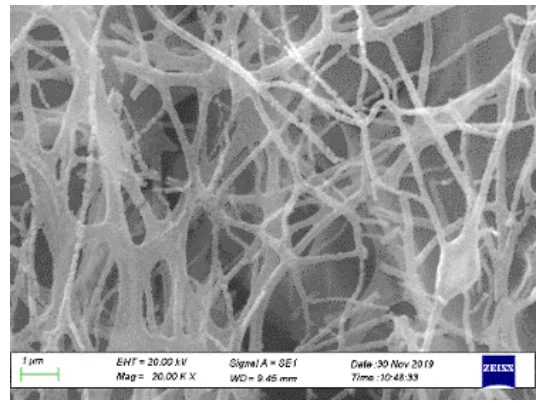

(d)

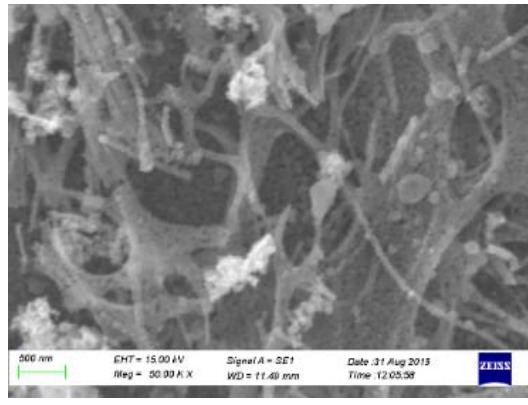

(b)

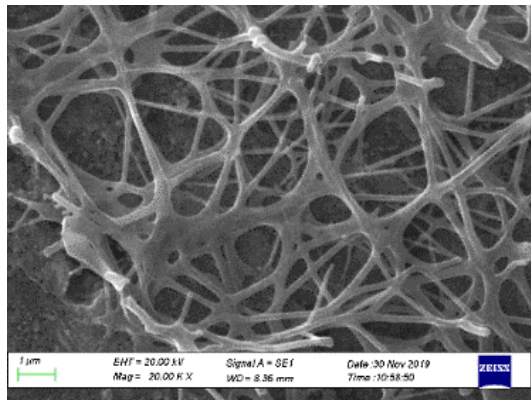

(e)

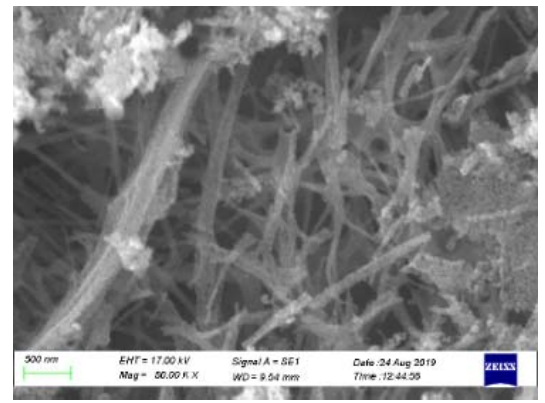

(c)

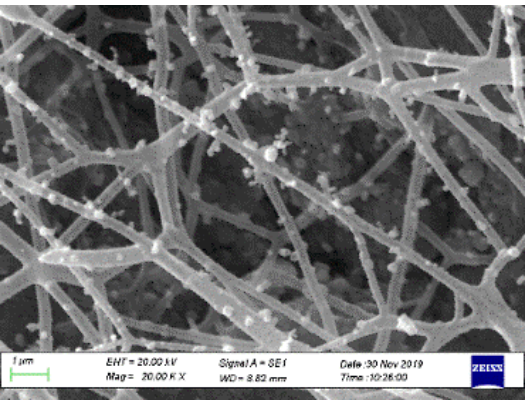

(f)

Figure $5 \mathrm{ZnO}$ semiconductor SEM photo results for variations of (a) $3 \mathrm{~cm}$ (b) $4 \mathrm{~cm}$ (c) $5 \mathrm{~cm}$ (d) $6 \mathrm{~cm}$ (e) $7 \mathrm{~cm}(f) 8 \mathrm{~cm}$.

Table 1. ZnO semiconductor diameter size for variations in flow rate.

\begin{tabular}{ccccc}
\hline $\begin{array}{c}\text { Flow } \\
\text { Rate } \\
\text { Variation } \\
(\boldsymbol{\mu L} /\end{array}$ & $\begin{array}{c}\text { Average } \\
\text { diameter } \\
\mathbf{( n m})\end{array}$ & $\begin{array}{c}\text { Maximum } \\
\text { diameter } \\
\mathbf{( n m})\end{array}$ & $\begin{array}{c}\text { Minimum } \\
\text { Diameter } \\
\mathbf{( n m})\end{array}$ & $\begin{array}{c}\text { Standard } \\
\text { deviation } \\
\mathbf{( n m})\end{array}$ \\
\hline 3 & 122.18 & 150.15 & 94.33 & \\
4 & 118.35 & 158.82 & 80.88 & 17.25 \\
5 & 125.43 & 175.52 & 100.23 & 15.16 \\
6 & 129.37 & 176.47 & 107.94 & 18.85 \\
7 & 134.45 & 175.50 & 95.45 & 16.20 \\
8 & 141.39 & 169.11 & 98.76 & 16.18 \\
\hline
\end{tabular}

Table 2. ZnO semiconductor diameter size for variations in distance.

\begin{tabular}{|c|c|c|c|c|}
\hline $\begin{array}{l}\text { Tip to } \\
\text { collector } \\
\text { distance } \\
(\mathbf{c m})\end{array}$ & $\begin{array}{c}\text { Average } \\
\text { diameter } \\
(\mathrm{nm})\end{array}$ & $\begin{array}{c}\text { Maximum } \\
\text { diameter } \\
(\mathrm{nm})\end{array}$ & $\begin{array}{c}\text { Minimum } \\
\text { Diameter } \\
(\mathrm{nm})\end{array}$ & $\begin{array}{c}\text { Standar } \\
\text { d } \\
\text { deviatio } \\
n(n m)\end{array}$ \\
\hline 3 & 140.4 & 170.21 & 97.80 & 16.28 \\
\hline 4 & 115.3 & 155.83 & 79.88 & 17.24 \\
\hline 5 & 107.3 & 141.49 & 67.59 & 17.52 \\
\hline 6 & 96.7 & 140.57 & 63.29 & 15.33 \\
\hline 7 & 92.7 & 126.20 & 49.45 & 16.12 \\
\hline 8 & 85.6 & 114.57 & 62.17 & 14.33 \\
\hline
\end{tabular}




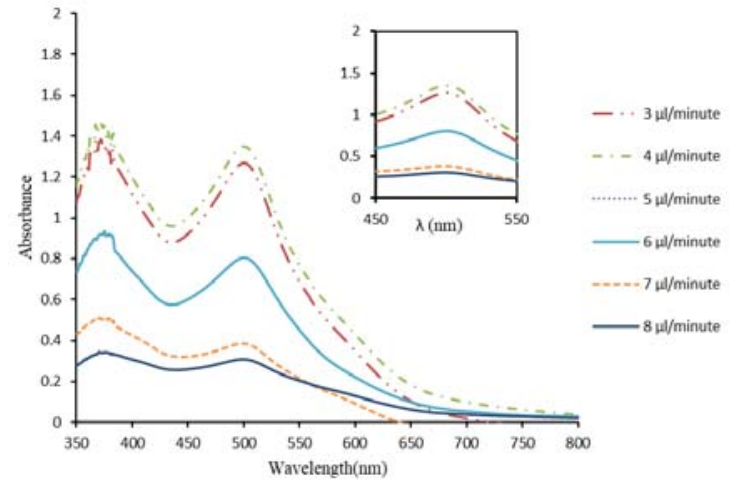

(a)

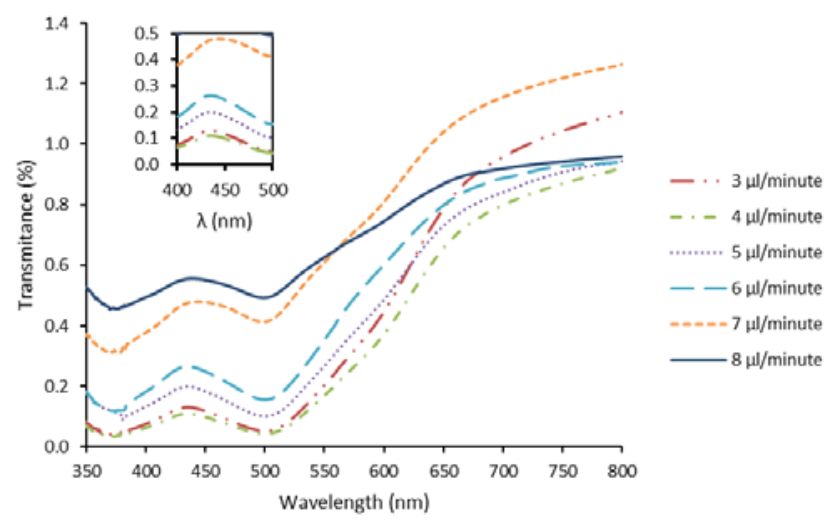

(b)

Figure 6. (a) The results of $\mathrm{ZnO}$ semiconductor absorbance tests for flow rate variations; (b) the results of $\mathrm{ZnO}$ semiconductor transmittance tests for flow rate variations.

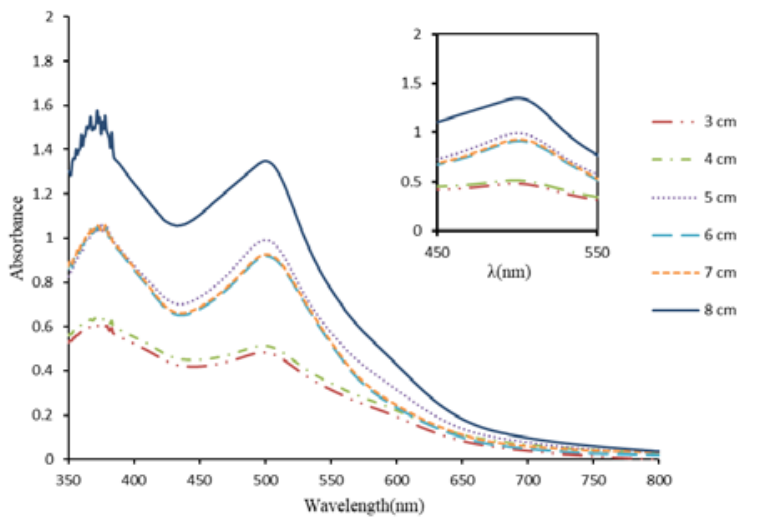

(a)

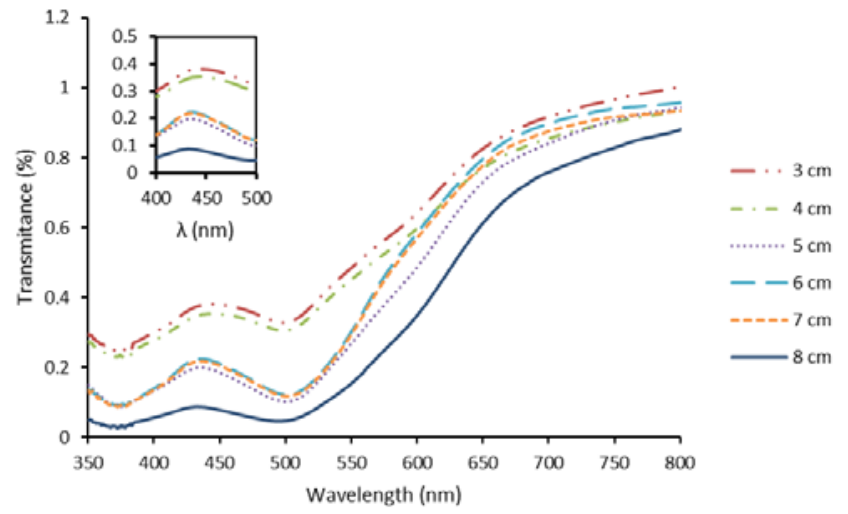

(b)

Figure 7. (a) ZnO semiconductor absorbance test results for distance variations; (b) ZnO semiconductor transmittance test results of distance variations.

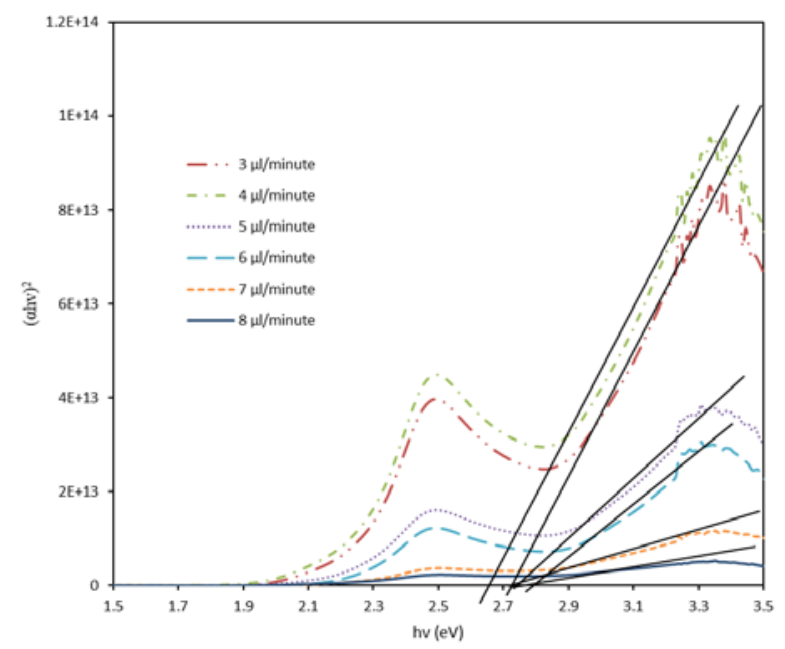

(a)

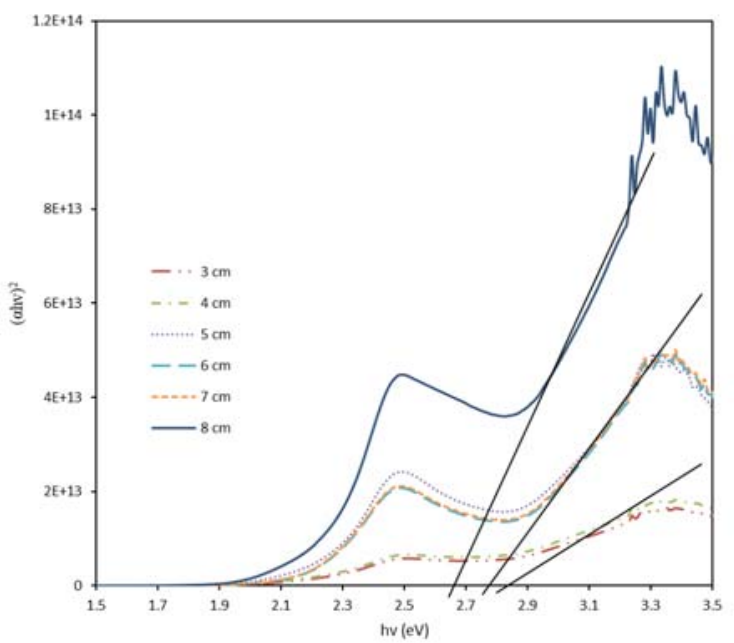

(b)

Figure 8. (a) Tauc's plot method used in determining the $\mathrm{ZnO}$ semiconductor band gap for variations in flow rate; (b) Tauc's plot method used in determining the $\mathrm{ZnO}$ semiconductor band gap for distance variations. 


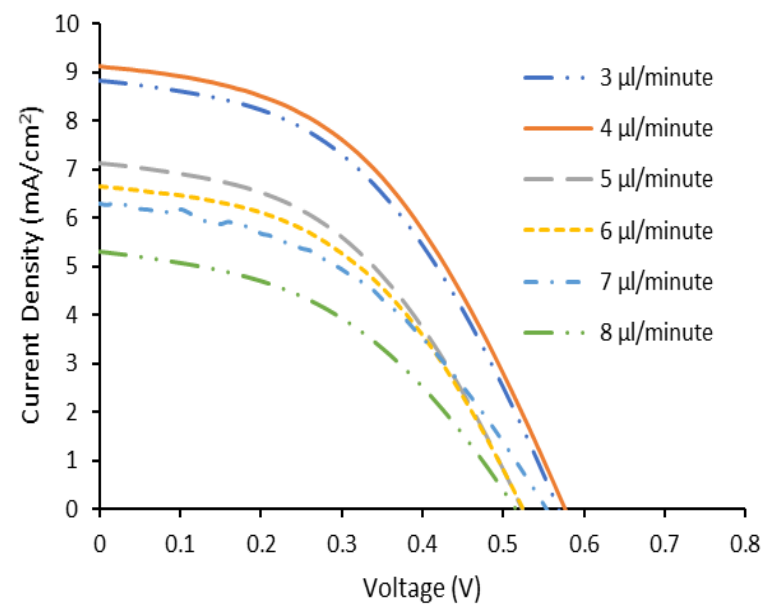

(a)

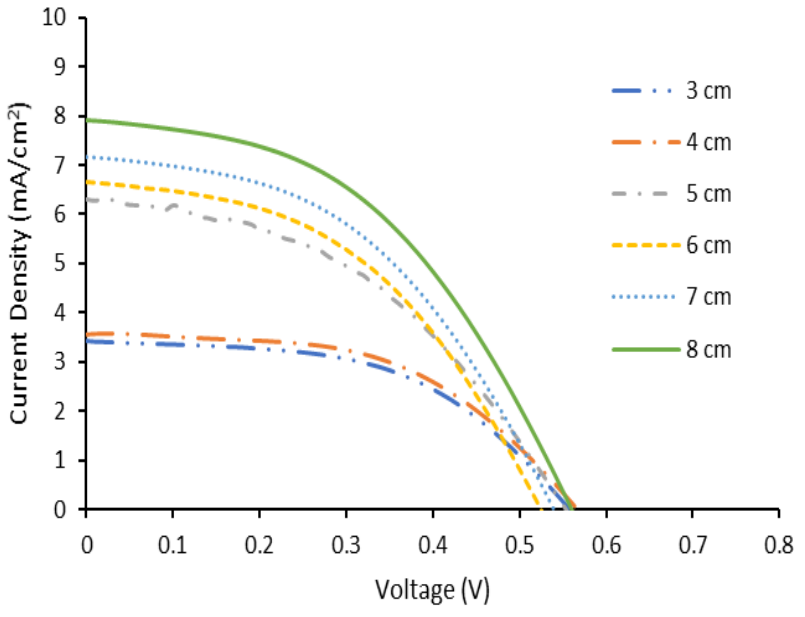

(b)

Figure 9. (a) IV curve of each flow rate variation; (b) IV curve of each tip-to-collector distance variation.

Table 3. DSSCs characteristics for flow rate variations.

\begin{tabular}{|c|c|c|c|c|c|}
\hline $\begin{array}{l}\text { Flow Rate } \\
\text { Variation } \\
\text { ( } \mu \mathrm{l} / \text { minute) }\end{array}$ & $\begin{array}{l}\text { VOC } \\
\text { (V) }\end{array}$ & $\begin{array}{c}\text { JSC } \\
(\mathrm{mA} / \mathrm{cm} 2)\end{array}$ & $\begin{array}{l}\text { Fill } \\
\text { Factor } \\
(\%)\end{array}$ & $\begin{array}{c}\text { Efficiency } \\
(\%)\end{array}$ & $\begin{array}{c}\text { Dye } \\
\text { Loading } \\
\left(\times 10^{-7}\right. \\
\left.\mathrm{mol} / \mathrm{cm}^{2}\right)\end{array}$ \\
\hline 3 & 0.56 & 8.84 & 45.80 & 2.27 & 1.17 \\
\hline 4 & 0.58 & 9.14 & 45.18 & 2.39 & 1.25 \\
\hline 5 & 0.53 & 7.14 & 45.09 & 1.71 & 0.74 \\
\hline 6 & 0.53 & 6.65 & 45.72 & 1.61 & 0.65 \\
\hline 7 & 0.55 & 6.29 & 44.13 & 1.53 & 0.35 \\
\hline 8 & 0.52 & 5.31 & 42.97 & 1.19 & 0.28 \\
\hline
\end{tabular}

Table 4. DSSCs characteristics for tip-to-collector distance variations.

\begin{tabular}{|c|c|c|c|c|c|}
\hline $\begin{array}{c}\text { Distance } \\
\text { Variation } \\
\text { (cm) }\end{array}$ & $\begin{array}{l}\text { VOC } \\
\text { (V) }\end{array}$ & $\begin{array}{c}\text { JSC } \\
(\mathrm{mA} / \mathrm{cm} 2)\end{array}$ & $\begin{array}{c}\text { Fill Factor } \\
\text { (\%) }\end{array}$ & $\begin{array}{c}\text { Efficiency } \\
(\%)\end{array}$ & $\begin{array}{c}\text { Dye } \\
\text { Loading } \\
\left(\times 10^{-7}\right. \\
\left.\text { mol/cm } \mathrm{cm}^{2}\right)\end{array}$ \\
\hline 3 & 0.56 & 2.71 & 52.02 & 0.79 & 0.44 \\
\hline 4 & 0.56 & 2.85 & 52.09 & 0.85 & 0.47 \\
\hline 5 & 0.55 & 4.49 & 44.13 & 1.09 & 0.81 \\
\hline 6 & 0.53 & 4.89 & 45.72 & 1.18 & 0.85 \\
\hline 7 & 0.54 & 5.66 & 45.45 & 1.39 & 0.86 \\
\hline 8 & 0.56 & 6.41 & 44.92 & 1.61 & 1.25 \\
\hline
\end{tabular}

Periódico Tchê Química. ISSN 2179-0302. (2020); vol.17 ( $\left.n^{\circ} 36\right)$ Downloaded from www.periodico.tchequimica.com 